\title{
Temporal Patterns in the Occurrence of Selected Tropical Fishes in Mangrove Creeks: Implications for the Fisheries Management in North Brazil
}

\author{
Tommaso Giarrizzo ${ }^{1,2 *}$ and Uwe Krumme ${ }^{2}$ \\ ${ }^{1}$ Laboratório de Biologia Pesqueira Manejo dos Recursos Aquáticos; Universidade Federal do Pará; Av. \\ Perimetra, 2651; 66040170; Belém - PA - Brasil. ${ }^{2}$ Center for Tropical Marine Ecology; Zentrum für Marine \\ Tropenökologie; Fahrenheitstr, 6; 28359; Bremen - Germany
}

\begin{abstract}
To examine the temporal patterns in the occurrence of a tropical ichthyofauna, fisheries-independent samples were collected between September 2003 and July 2004 from intertidal mangrove creeks in the Curuçá estuary, Pará, north Brazil. Juveniles occurred year-round with the most intense occurrence during the wet/dry transition season (Anchovia clupeoides, Cetengraulis edentulus, Rhinosardinia amazonica, Mugil sp.). The occurrence of Colomesus psittacus and Anchoa hepsetus was continuous. Sciades herzbergii displayed two peaks (wet and dry season) while Cathorops sp. peaked only in the wet season. The continuous presence of juveniles in the tropical mangroves suggested that the fisheries management should be based on large no-take areas rather than closed seasons.
\end{abstract}

Key words: fish recruitment, juvenile fish, mangrove estuary, tropical fisheries management, Curuçá, Brazilian Amazon

\section{INTRODUCTION}

About $20 \%$ of the total fisheries landings of Brazil come from the marine and estuarine fisheries of the northern states Amapá and Pará (IBAMA, 2004; Isaac et al., 2006). Fishes account for $89 \%$ of the catches in north Brazil and are the most important resource in this region (IBAMA, 2004). Despite the economic importance of the coastalmarine fisheries north and south of the mouth of the Amazon River, its management is precarious. Increasing fishing pressure on estuarine and associated mangrove ecosystems and forms of illegal fishing are posing serious threats to some species and ecosystem biodiversity.
Fisheries management is in part based on nonecological considerations. Yet, many management decisions are made without the vital biological data on the diverse tropical ichthyofauna and its economically important fish species in north Brazil. Important basic information, such as the temporal patterns in the occurrence of juveniles of many fish species, has thus far not been investigated.

Studies on habitat use and the biological cycles of the fishes are essentially limited to the south of Brazil. Moreover, the Brazilian fisheries legislation defines closure periods only for commercially important tropical stocks in north Brazil (e.g. Lutjanus purpureus). However, no

\footnotetext{
Author for correspondence: tgiarrizzo@gmail.com
} 
management actions have been implemented to protect the juveniles, spawning grounds or spawning seasons of non-commercial fishes. These fish species account for the broad ichthyofaunal diversity in the region and are targeted by the subsistence and the artisanal fisheries.

A survey in 2003 showed that from the total fish landings in north Brazil, 90\% came from the artisanal fisheries (IBAMA, 2004; Isaac et al., 2006). Despite the paucity of statistical data on the fisheries production in the Brazilian mangrove areas, the estimates indicate that, in some states, the mangrove ecosystems contribute up to $50 \%$ of the total artisanal fisheries production. A survey of the artisanal fishery landings in 2000/2001 in Bragança, the third largest landing site in Pará, revealed that the intertidal fisheries contributed $46 \%$ to the total landings (Espírito Santo, 2002).

The macrotides (2-7 m tidal range) along the north Brazilian coast expose extensive mudflats and sandbanks to the air each tide. The high intertidal zone of the states of Pará and Maranhão is covered by approximately $7,000 \mathrm{~km}^{2}$ of almost undisturbed mangrove forests (Kjerfve and Lacerda, 1993) the second largest contiguous mangrove area of the world. Due to the structural complexity, shallowness and high turbidity, mangroves provide shelter, food and shadow for juvenile fishes and shrimps and are, therefore, considered important nursery grounds worldwide (e.g. Laegdsgaard and Johnson, 1995; 2001; Vendel et al., 2002). Many fishes directly use the mangrove at least during some period of their life cycle, or may indirectly rely on the resources derived from it.

The mangrove areas connect the high intertidal zone where many fishes forage during high tides, with the subtidal areas where the fishes reside during the low water period. Common artisanal fishing methods take advantage of the regular tidal migrations connecting different intertidal fish habitats and consequently, target the fishes in their nursery environment. For instance, block nets are set inside the mangrove area while large intertidal fish weirs are constructed on sand banks (Isaac and Barthem, 1995; Barletta et al., 1998). While a minimum mesh size of $80 \mathrm{~mm}$ is defined for block nets, fixed fishing techniques such as fish weirs are completely prohibited (SUDEPE, 1988). Nevertheless, hundreds of fish weirs are installed along the coast of Pará. Around 30\% of the total catch weight is discarded as by-catch (Schaub, 2000) which often includes juvenile stages of several commercial species, thus having adverse effects on the adult stock and their fisheries.

To provide more scientific information on the fish fauna in north Brazil, this study analyzed the temporal variation in the occurrence of juveniles of eight abundant fish species from the intertidal mangrove creeks of the Curuçá estuary, a marine conservation unit (marine extractive reserve) on the eastern tip of the Pará River mouth. The species were members of the families Engraulidae (Anchoa hepsetus, Anchovia clupeoides, Cetengraulis edentulus), Clupeidae (Rhinosardinia amazonica), Tetraodontidae (Colomesus psittacus), Ariidae (Cathorops sp., Sciades herzbergii) and Mugilidae (Mugil sp.). Except for Ariidae and Mugilidae, the species studied here are not of economic importance. Nevertheless, they are linked to higher trophic levels via the food web.

The year-round high proportion of juvenile fishes in the creeks (80-90\%) suggested that (1) the intertidal mangrove creeks generally deserve a high conservation status; (2) temporal closures are inappropriate; and (3) instead, spatial closures are most suitable for these tropical fish stocks. Given the increasing fishing pressure, large no-take areas (Marine Protected Areas) using a "whole-estuary" approach would likely be most appropriate for a sustainable management of these valuable fisheries resources.

\section{MATERIAL AND METHODS}

\section{Study area}

The study was carried out in four intertidal mangrove creeks in the upper and middle reaches of the Curuçá estuary $\left(0^{\circ} 10^{\prime} \mathrm{S}, 47^{\circ} 50^{\prime} \mathrm{W}\right)$. The Curuçá estuary is a marine-dominated system with little freshwater input. It is covered by approximately $116 \mathrm{~km}^{2}$ of mangrove forest dominated by Rhizophora mangle L. mixed with Avicennia germinans (L.) on the more elevated sites. The creeks (approximately $4 \mathrm{~km}$ apart) are located within a zone of homogeneous salinity. In this zone temperature, $\mathrm{pH}$, turbidity, oxygen content and biological oxygen demand displayed no significant spatial differences (Giarrizzo and Krumme, 2007). There is a dry season from July to December (salinities $>25$ ) and a wet season from January to June (salinities $<15$ ). The mean annual rainfall is $2,526 \mathrm{~mm}$. The semidiurnal tide ranges 
between 3-4 $\mathrm{m}$ at neap tides and $4-5 \mathrm{~m}$ at spring tides.

\section{Fish collection}

Four creeks were sampled bimonthly between September 2003 and July 2004 at four consecutive days during the waxing of the moon (neap tide) with a fyke net (two wings, $20 \times 6 \mathrm{~m}$, and a hoopnet with $20 \mathrm{~mm}$ and $13 \mathrm{~mm}$ stretched mesh size, respectively), yielding a total of 24 samples. The fyke net was set at the mouth of the creeks at daytime slack high water (HW). During the ebb tide, the fishes were collected until the total drainage of the creek and kept on ice.

\section{Catch analysis}

For the eight most abundant species, total length (TL) was measured $( \pm 1 \mathrm{~mm})$ and wet-weight was determined $( \pm 0.01 \mathrm{~g})$. Each creek was surveyed to generate an estimate of the inundated area $\left(\mathrm{m}^{2}\right)$ for a medium neap tide event using ArcGIS. Fish abundance was standardized to density (fish $\mathrm{m}^{-2}$ ).

We use Cathorops sp. (Ariidae) for a catfish locally called "Uricica branca" (Krumme et al., 2004). Mugil sp. was used for a species identified as Mugil gaimardianus because the original description does not clearly define the species and M. gaimardianus is an invalid name (I. Harrison, American Museum of Natural History, pers. comm.). Gonad inspection was used to distinguish juveniles from adult fishes. About $90 \%$ of all the fishes caught were juveniles (Giarrizzo and Krumme, 2007). Since adults use the intertidal creeks only occasionally, these were excluded from the temporal analysis.

\section{Data analysis}

For each month, the catches from the four creeks were pooled. The periods of occurrence in the intertidal mangrove creeks were inferred from the changes in density and mean length of juveniles. The Kruskal-Wallis test was used to ascertain whether the density of juveniles changed between months. The Nemenyi test was used for post-hoc analysis. The temporal similarities in the density of the species was assessed using cluster analysis (complete linkage) based on Bray-Curtis similarity measures (Primer 5; Clarke and Warwick, 1994). As abundances between the species differed by two orders of magnitude, data were $\log (x+1)$ transformed.

\section{RESULTS AND DISCUSSION}

The juveniles of A. clupeoides, A. hepsetus, $C$. psittacus, $C$. edentulus, $R$. amazonica, $S$. herzbergii, Mugil sp., and Cathorops sp. accounted for $38.8,20.4,12.2,11.3,7.2,6.4,3.3$ and $0.4 \%$ of the total of 45,314 fishes collected, respectively. The densities of juvenile $C$. edentulus, Cathorops sp. and Mugil sp. changed significantly between the months (KW test, $\mathrm{p}<$ 0.05) (Fig. 1e,f,a). The densities of $C$. edentulus were significantly higher in May than in March and November (Nemenyi test, $\mathrm{p}<0.01$ ). The densities of Cathorops sp. were significantly higher in May than in January, September and November (Nemenyi test, $\mathrm{p}<0.1$ ). No significant post-hoc differences were detected for Mugil sp., likely due to the large variations in the density. In $R$. amazonica, there was a trend for higher densities in September than in May (Fig. 1b). There were no significant differences in the densities of juveniles of A. clupeoides, A. hepsetus, S. herzbergii, and C. psittacus (Fig. 1c, d, g,h).

The cluster analysis separated two groups (Fig. 2) at a similarity of $38 \%$. Group I consisted of four fish species with higher densities during the wet season. Group II consisted of four fish species with higher densities during the dry season.

Fig. 3 shows the months when the smallest or largest juveniles were found in the creeks. The temporal pattern was clearest in the dry season group (Fig. 3a-d), and is therefore discussed first. The smallest juveniles occurred in September and July during the dry season while the largest juveniles occurred usually in March (wet season). In these species, the highest juvenile densities coincided with the smallest mean fish sizes (Fig. 1, 3).

On the species level, the temporal patterns from the dry season group were as follows:

\section{Mugil sp.}

The average length of the young-of-the-year mullets increased slightly from May to September (Fig. 3a), indicating an extended period of juvenile occurrence during the wet/dry season transition period and growth of the cohort during the dry season. The high densities in September 2003 could be attributed to the schooling behavior of juvenile Mugil sp. and the random capture of some schools in the creeks. Sikoki et al. (1998) showed a similar temporal pattern for M. cephalus in 
Nigeria with a protracted spawning period between September and December from the late rainy season to the early dry season.

The only area that could be used for comparison was the Caeté estuary located ca. $150 \mathrm{~km}$ east of the Curuçá estuary. Ichtyoplankton samples taken in the main channel and in the intertidal mangrove creeks there (Barletta-Bergan et al., 2002a,b) did not catch larvae of mullets, indicating that spawning could occur along the coast and the juveniles use the mangrove habitat as nursery grounds. A similar breeding cycle was found for Mugilidae in the coastal waters of the Indo-West Pacific (Blaber, 1987).
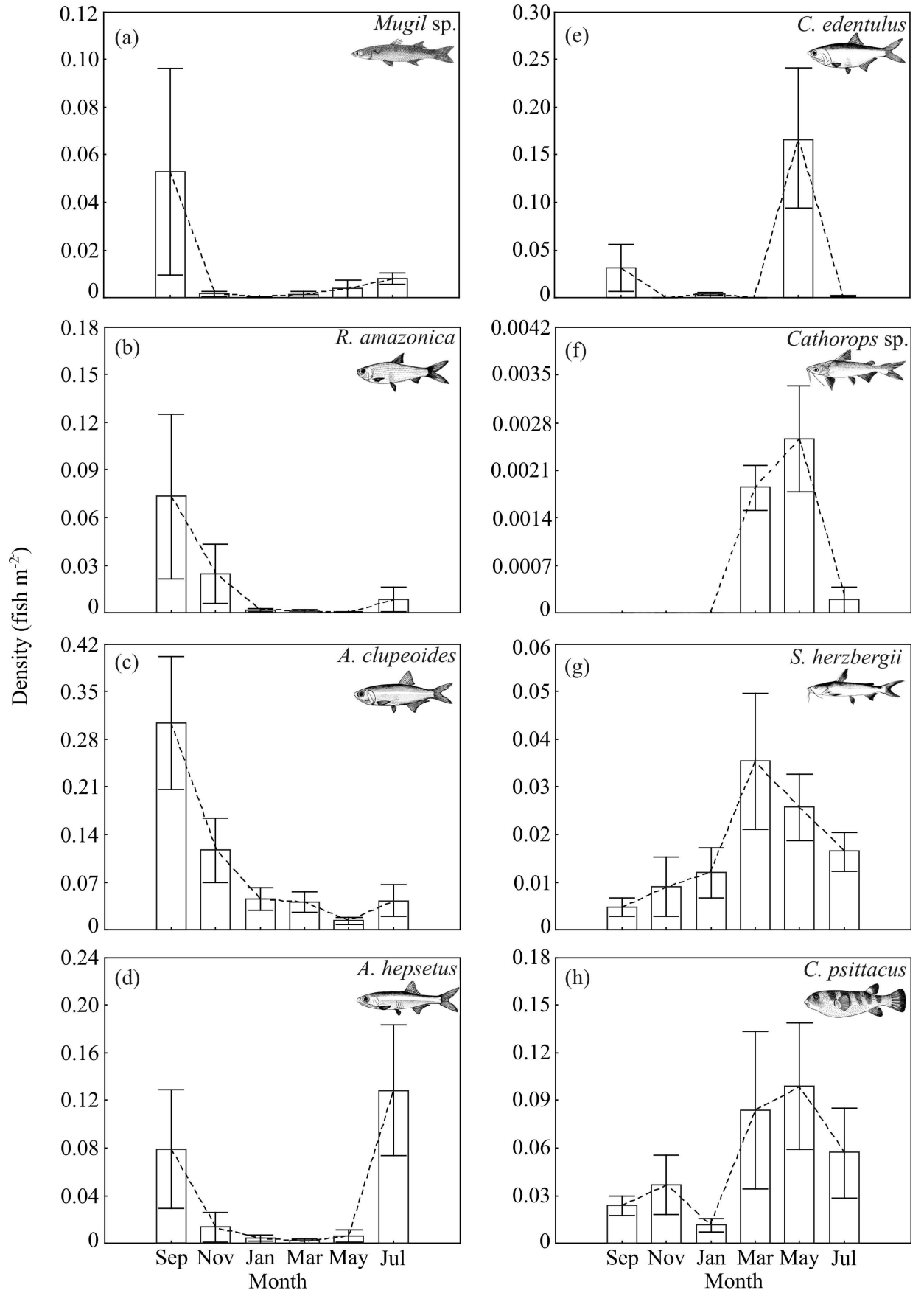

Figure 1 - Mean density (juvenile fish $\mathrm{m}^{-2} \pm 1 \mathrm{SE}$ ) of the eight most abundant fish species collected bimonthly from four intertidal mangrove creeks in the Curuçá estuary, Pará, north Brazil, between September 2003 and July 2004. 


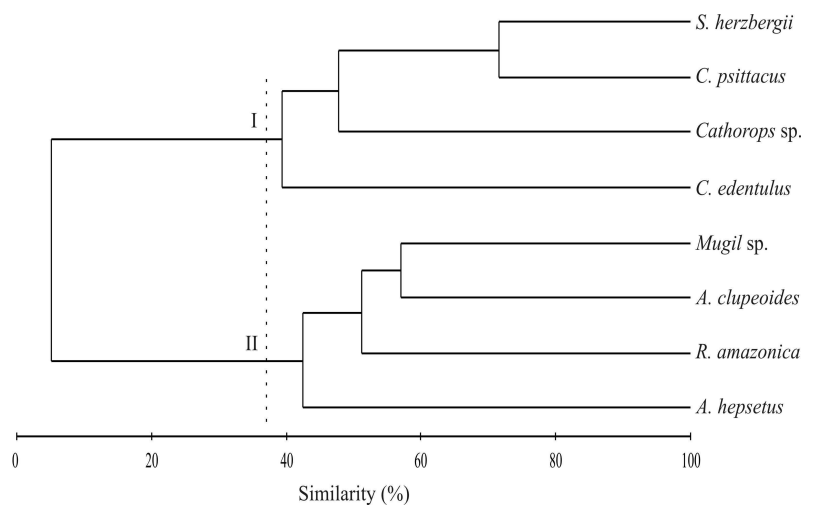

Figure 2 - Dendrogram showing the clustering results of the density of the juveniles of the eight most abundant fish species collected from intertidal mangrove creeks in the Curuçá estuary (north Brazil) between September 2003 and July 2004. Two groups were separated at $38 \%$ similarity.

\section{Rhinosardinia amazonica}

The lack of significant changes in the length of $R$. amazonica between September, November and also in July (Fig. 3b) suggested an extended recruitment of the young-of-the-year during the wet/dry season transition and in the late dry season. Estuarine spawning occured primarily in the dry season as indicated by the high abundances of yolk-sac larvae of $R$. amazonica in the Caeté estuary (Barletta-Bergan, 1999, p. 71).

\section{Anchovia clupeoides}

The smallest juvenile A. clupeoides were caught between September, November and July (Fig. 3c) suggesting the extended occurrence of one major cohort per year with a spawning peak during the wet/dry season transition in June/July. Likewise in the Caeté system, the peak spawning activities occurred during the early wet season in the upper estuary; spawning seemed to occur pelagically in the estuarine bay and eggs were poorly represented in the mangrove creeks (Barletta-Bergan et al., 2002a,b).

\section{Anchoa hepsetus}

In the creeks, the mean size of juvenile A. hepsetus did not change during the year (Fig. 3d). This suggested that first, a particular size- (or age-) specific subgroup of the population was continuously using the intertidal mangrove creeks. Fifty percent of the A. hepsetus caught measured between 3.3 to $4.4 \mathrm{~cm}$ TL. Thus, A. hepsetus used different estuarine habitats at different points in its life cycle, changing to another habitat at a certain size. Second, the juvenile recruitment has to be continuous. Third, the reproductive activity of the adults was also continuous. In Mexico, the reproductive season of $A$. hepsetus extended throughout the year (Valencia et al., 1998). Higher densities in September and July suggested that the early dry season was an important period for the juvenile recruitment.

The temporal pattern of the wet season group was more complex (Fig. 3e-h). Except for Cathorops sp. (see below), the juveniles of all species used the intertidal mangrove creeks throughout the year. On the species level, the temporal patterns from the wet season group were as follows:

\section{Cetengraulis edentulus}

The mean size of juvenile $C$. edentulus increased from September to May suggesting that a single cohort was using the intertidal creeks during most of the year (Fig. 3e). Assuming a growth rate of $13.3 \mathrm{~mm}$ month $^{-1}$ (Sergipense and Sazima, 1995) and count back from September, the major reproductive period likely occured in the wet/dry season transition in about May. Both the specimens $<5 \mathrm{~cm}$ and $>12 \mathrm{~cm} \mathrm{TL}$ were essentially absent from the creeks in Curuçá. The fyke net captured fishes of only $2 \mathrm{~cm}$ TL. That $C$. edentulus $<5 \mathrm{~cm}$ were not found reflected their absence from the entire creek habitat. BarlettaBergan et al. (2002a,b) caught insignificant numbers of larvae of $C$. edentulus, both in mangrove creeks and in the Caeté Bay. Consequently, there have been significant ontogenetic changes in habitat use and different coastal estuarine habitats which must be 
interlinked by active movements of the size classes. In Venezuela, C. edentulus spawned near the coast in the wet season at night (Simpson, 1985). Hence, the eggs and the early life stages likely occured along the coast. The juveniles and subadults used the intertidal creeks as important feeding grounds (Keuthen, 1998) while the adults that were rarely caught in the intertidal creeks (Barletta et al., 2003), were found again in coastal waters.

\section{Cathorops sp.}

Unlike the year-round dominance of Cathorops sp. in the block net samples from the intertidal mangrove creeks in the Caeté system (Barletta et al., 2003), the juveniles occurred in the creeks of the Curuçá system only in the wet season where they displayed a minor size increase from March to July (Fig. 3f). The absence of Cathorops sp. in the dry season could be linked to a longitudinal shift in the estuarine distribution. Cathorops sp. has been described as withdrawing to the lower salinity regions during the dry season (pers. comm. with fishermen). In the main channel of the Curuçá estuary, trawl samples showed that Cathorops sp. had one clear peak in gonadal maturity during the dry/wet season transition (December/January) (Giarrizzo, unpubl. data). In the Caeté system, mouth-breeding males of Cathorops sp. were absent from dry season lift net catches while the gonadosomatic index of females increased towards the end of the dry season (Leal-Florez, 2001). During the wet season, male Cathorops sp. incubated embryos (Barletta et al., 2003, Krumme et al., 2004). The reproductive activity during the wet season coincided with the highest biomass and density (Barletta et al., 2003, Giarrizzo and Krumme, 2007), emphasizing the importance of the intertidal mangrove creeks for the reproductive period of Cathorops sp.

\section{Sciades herzbergii}

The smallest juvenile $S$. herzbergii were caught in September suggesting the occurrence of a new cohort in the early dry season (Fig. 3g). In March, there was another decrease in the mean LT, though less pronounced, suggesting the occurrence of a second cohort in the wet season. Cohort analysis of catches from Curucá showed that $S$. herzbergii exhibited a spawning period in January and probably also in August (Giarrizzo and Saint-Paul, 2008). The brief time period between the spawning and the occurrence of the cohort accorded with the time necessary to release the fully functional juveniles [10-12 days for oral incubation by the males and 50-60 days until the release of the juveniles (Chacon et al., 1994)]. In Ceará (Chacon et al., 1994) and French-Guyana (Le Bail et al., 2000), S. herzbergii had two reproduction cycles per year, which demonstrated that when there were two reproduction periods per year, a bimonthly sampling might not be precise in tracking temporal changes in the occurrence of new cohorts.

\section{Colomesus psittacus}

In the creeks, there were no major changes in the mean size of juvenile $C$. psittacus during the year (Fig. 3h). This suggested that, first, a size- (or age) specific subgroup of the resident population was continuously using the intertidal mangrove creeks. Fifty percent of the $C$. psittacus caught measured 7 to $13 \mathrm{~cm}$ TL. Second, the juvenile occurrence has to be continuous. Third, the reproductive activity of the adults must also be continuous. The larvae of $C$. psittacus were rare both in the creeks and in the Caeté Bay (Barletta-Bergan et al., 2002a,b). Scientific beach seine catches in the Caeté system (Krumme et al., 2004) and in Curuçá (Giarrizzo, unpubl. data) found that the shallow unvegetated mud flats fronting the mangrove forest were an important habitat for juvenile $C$. psittacus with a mean size of only $2-3 \mathrm{~cm}$ TL. The minimal numbers of large adults in the creeks suggested that other estuarine habitats, such as the deeper waters characteristic of the open bay, were more important. This was supported by the regular occurrence of adult $C$. psittacus in the intertidal fish weirs (Schaub, 2000). The different estuarine habitats that were being used by different size classes of resident $C$. psittacus are likely connected by regular tidal migrations.

\section{Conclusions and implications for fisheries management}

The analysis of temporal changes in the density and mean length of juveniles was a useful approach to derive patterns in the occurrence of abundant mangrove fishes. Although the samples were taken only bimonthly, the sample sizes were sufficiently high to analyze changes in times. Monthly samples would provide more detailed results, e.g. linked to cohort analysis, but this would require greater investigative effort in both sampling and analysis. 

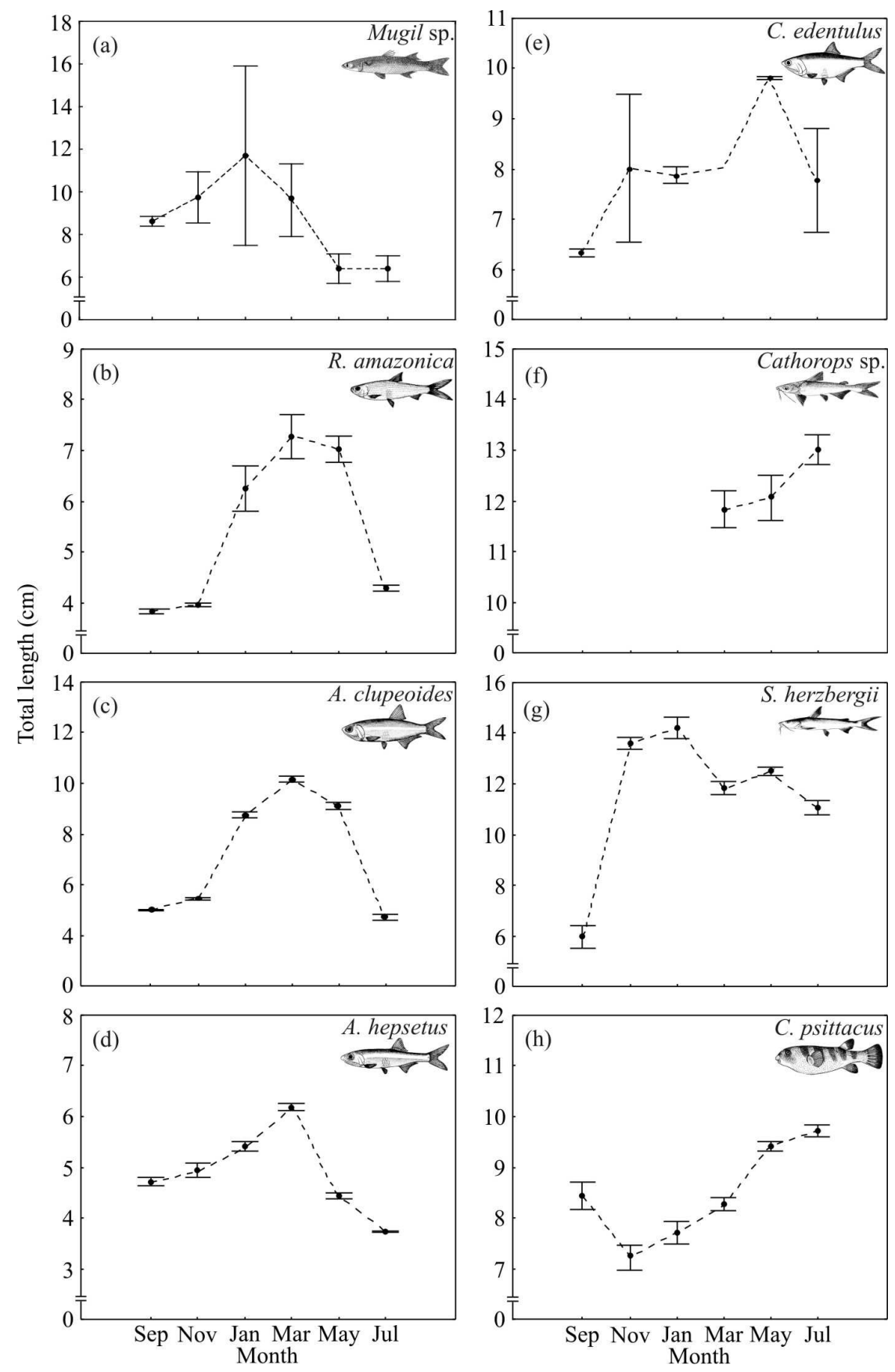

Figure 3 - Changes in total length (mean and 95\% confidence interval) of juveniles of the eight most abundant fish species collected bimonthly from intertidal mangrove creeks in the Curuçá estuary (north Brazil) between September 2003 and July 2004.

The juvenile occurrence was most intense during the wet/dry season transition (four species). Two species displayed a continuous occurrence of juveniles ( $C$. psittacus, A. hepsetus). S. herzbergii displayed two occurrence peaks (wet and dry season) while Cathorops sp. peaked only in the wet season. Considering only the eight species studied here, it was evident that there was no single well-defined period of juvenile occurrence characteristic of the mangrove area. The juveniles of most species were present year round as was also shown by Barletta et al. (2003). This is a common pattern in tropical coastal fish communities and in contrast to the occurrence 
patterns of temperate zones which are mostly related to seasonal changes in temperature or day length (Longhurst and Pauly, 1987). The wide array of reproductive strategies of tropical estuarine fishes suggested that temporal closures in tropical regions are inappropriate.

The almost exclusive use of intertidal mangrove creeks by only the juvenile size classes and the absence of the fishes in the earliest phase of life as well as mature adulthood indicated that these fishes relied on different estuarine habitats during their life cycle. These habitats were interconnected by regular tidal or ontogenetic movements of the fishes (Sheaves, 2005). The identification of the key nursery areas could be useful to protect a particular size class, yet on the other hand it might not be possible to protect the habitat requirements of a species throughout its life cycle. It, therefore, is suggested that the "whole-estuary approach" might be the most appropriate management unit. The establishment of marine protected areas (MPAs) could be a useful tool in the management of living coastal resources (e.g. Salm et al., 2000).

Along the coast of Pará and Maranhão, there are more than thirty mangrove estuaries which remain relatively undisturbed (Giarrizzo and Krumme, 2008). Nine have been declared as marine extractive reserves. However, a broadbased ecology preservation has been premised on nonecological considerations due to the lack of relevant biological knowledge of the fisheries resources of the north Brazilian coast, i.e. the conservation legislation has focused on the social interests of the local governments (prefeituras) and/or the community organizations (e.g. associações de pescadores). The present results highlight the urgent need for further and expanded investigation to obtain results (e.g. on vital nursery areas and habitat connectivity), which would help to identify the locations and requirements of conservation necessary to preserve these important habitats in the future.

\section{ACKNOWLEDGEMENTS}

The authors thank A. Jesus, B. Almeida, E. Lameira, D. Monteiro, F. Arnour and J. Kikuchi for assistance in field collections and laboratory analyses. This work was funded by the Millennium Initiative Project "Coastal Resources" (www.mileniodomar.org.br), financed by the Brazilian Ministry of Science and Technology and the project MADAM. T. Giarrizzo acknowledges financial support by the Fundação de Amparo à Pesquisa do Estado do Pará (FAPESPA) (Project number: 137/2008 - Universal). U. Krumme acknowledges financial support by the German Ministry for Education, Science, Research and Technology (BMBF) within the cooperation between the Center for Tropical Marine Ecology (ZMT), Bremen, Germany, and the Univ. Federal do Pará (UFPa), Belém, Brazil, under the Governmental Agreement on Cooperation in the Field of Scientific Research and Technological Development between Germany and Brazil [Project number: 03F0253A5, Mangrove Dynamics and Management - MADAM].

\section{RESUMO}

Com o objetivo de examinar padrões temporais em recrutamento de uma ictiofauna tropical, pescarias experimentais foram realizadas entre setembro 2003 e Julio 2004 em canais de maré com vegetação de mangue no estuário do rio Curuçá, Pará, Norte do Brasil. Juvenis ocorreram durante todo o ano, entretanto com maior intensidade no período de recrutamento, durante a transição da estação chuvosa para a seca (Anchovia clupeoides, Cetengraulis edentulus, Rhinosardinia amazonica, Mugil sp.). O recrutamento foi continuo para Colomesus psittacus e Anchoa hepsetus. Sciades herzbergii apresentou dois picos de recrutamento (estação chuvosa e seca), entretanto Cathorops sp. teve somente um (estação chuvosa). A presença contínua de juvenis nos manguezais sugere que o manejo da pesca em regiões tropicais com vegetação de mangue deveria se direcionar em definir grandes áreas de proteção ao lugar de épocas de defeso.

\section{REFERENCES}

Barletta, M.; Barletta-Bergan, A. and Saint-Paul, U. (1998), Description of the fisheries structure in the mangrove-dominated region of Bragança (State of Pará). Ecotropica, 4, 41-53.

Barletta, M.; Barletta-Bergan, A.; Saint-Paul, U. and Hubold, G. (2003), Seasonal changes in density, biomass, and diversity of estuarine fishes in tidal mangrove creeks of the lower Caeté Estuary (northern Brazilian coast, east Amazon). Mar. Ecol. Prog. Ser., 256, 217-228. 
Barletta-Bergan, A. (1999), Structure and seasonal dynamics of larval and juvenile fish in the mangrovefringed estuary of the Rio Caeté in North Brazil. PhD Thesis, Zentrum für Marine Tropenökologie, University of Bremen, Germany.

Barletta-Bergan, A.; Barletta, M. and Saint-Paul, U. (2002a), Community structure and temporal variability of ichthyoplankton in North Brazilian mangrove creeks. J. Fish. Biol., 61, 33-51.

Barletta-Bergan, A.; Barletta, M. and Saint-Paul, U. (2002b), Structure and seasonal dynamics of larval fish in the Caeté River Estuary in North Brazil. Estuar. Coast. Shelf Sci., 54, 193-206.

Blaber, S. J. M. (1987), Factors affecting recruitment and survival of Mugilidae in estuaries and coastal waters of the Indo-West Pacific. American Fisheries Society Symposium, 1, 507-518.

Chacon, J. O.; Alves, M. I. M. and de Mesquita, M. S. C. (1994), Alguns aspectos da reprodução do bagre branco, Selenapsis herzbergii (Bloch 1794), Pisces: Ostariophysi, Siluriformes, Ariidae. Bol. Tec. DNOCS, Fortaleza, 47/52, 43-78.

Clarke, K. R. and Warwick, R. M. (1994), Change in marine communities: an approach to statistical analysis and interpretation. Natural Environment Research Council, Plymouth.

Espírito Santo, R. (2002), Caracterização da atividade de desembarque da frota pesqueira artesanal de pequena escala na região estuarina do rio Caeté, município de Bragança-Pará-Brasil. Master Thesis, Universidade Federal do Pará, Brazil.

Giarrizzo, T. and Krumme, U. (2007), Spatial differences and seasonal cyclicity in the intertidal fish fauna from four mangrove creeks in a salinity zone of the Curuça estuary, North Brazil. Bull. Mar. Sci., 80, 739-754.

Giarrizzo, T. and Krumme, U. (2008), Heterogeneity in intertidal fish fauna assemblages along the world's longest mangrove area in northern Brazil. J. Fish Biol., 72, 773-779.

Giarrizzo, T. and Saint-Paul, U. (2008), Ontogenetic and seasonal shifts in the diet of the pemecou sea catfish Sciades herzbergii (Siluriformes: Ariidae), from a macrotidal mangrove creek in the Curuçá estuary, Northern Brazil. Rev. Biol. Trop., 56, 861873.

IBAMA (2004), Estatistica da pesca 2003. Brasília, Brazil.

Isaac, V. J. and Barthem, R. B. (1995), Os recursos pesqueiros na Amazônia brasileira. Bol. Mus. Para. Emílio Goeldi, 11, 295-339.
Isaac, V. J.; Espirito Santo, R. V.; Silva, B. B.; Castro, E.; and Sena, A. L. (2006). Diagnostico da pesca no mlitoral do estado do Para. In: Isaac, V. J.; Martins, A. S.; Haimovici, M. and Andriguetto, J. M. (2006). A pesca marinha e estuarina do Brasil no Início do século XXI: Recursos, tecnologias, aspectos socioeconômicos e institucionais. Belém: Editora Universitária - Universidade Federal do Pará, p. 1140.

Kjerfve, B., and de Lacerda, L. D. (1993), Mangroves of Brazil. In: de Lacerda, L.D. (Ed.) Mangrove ecosystems technical reports ITTO TS-13, 245-272.

Keuthen, H. (1998), Nahrungsökologische Untersuchungen an ausgewählten Beispielen der Ichthyofauna der Mangrove vor Braganca (Pará, Brasilien). Diploma thesis, Center for Tropical Marine Ecology (ZMT), University of Hamburg, Germany.

Krumme, U.; Saint-Paul, U. and Rosenthal, H. (2004), Tidal and diel changes in the structure of a nekton assemblage in small intertidal creeks in northern Brazil. Aquat. Living. Resour., 17, 215-229.

Laegdsgaard, P. and Johnson, C. R. (1995), Fish communities in subtropical mangroves and adjacent habitats: the importance of nurseries for commercial species. Mar. Ecol. Prog. Ser., 126, 67-81.

Laegdsgaard, P. and Johnson, C. R. (2001), Why do juvenile fish utilize mangrove habitats? J. Exp. Mar. Biol. Ecol., 257, 229-253.

Leal-Florez, J. (2001), Feeding ecology of Uricica branca, Cathorops agassizii (Pisces: Ariidae), in an intertidal channel of the Caeté estuary, Northern Brazil. Master thesis, Center for Tropical Marine Ecology (ZMT), University of Bremen, Germany.

Le Bail, P. Y.; Keith, P. and Planquette, P. (2000), Atlas des poissons d'eau douce de Guyane (tome 2, fascicule II). Publications scientifiques du M.N.H.N, Paris.

Longhurst, A. R. and Pauly, D. (1987), Ecology of tropical oceans. Academic Press, San Diego

Salm, R. V.; Clark, J. and Siirila, E. (2000), Marine and coastal protected areas: a guide for planners and managers. IUCN, Washington DC.

Schaub, C. M. (2000), Untersuchung der Grossreusenfischerei im Ästuar des Rio Caeté/Nordbrasilien. Diploma thesis, Center for Tropical Marine Ecology (ZMT), University of Bremen, Germany.

Sergipense, S. and Sazima, I. (1995), Variações sazonais de ocorrência e tamanho em duas espécies de Engraulididae (Osteichthyes) na Baía de Sepetiba, Rio de Janeiro. Rev. Bras. Biol., 55, 491-501. 
Sheaves, M. (2005), Nature and consequences of biological connectivity in mangrove systems. Mar. Ecol. Prog. Ser., 302, 293-305.

Sikoki, F. D.; Hart, S. A.; Hart, A. I. and AdeleyeWokoma, I. P. (1998), Aspects of the reproductive biology of Mugil cephalus (Linnaeus, 1857) in Bonny Estuary. Proc. Annu. Conf. Fish. Soc. Niger., 82-88

Simpson, J. G. (1985), A study of the early life history of the rabo amarillo, Cetengraulis endentulus (Cuvier), in eastern Venezuela. Republica de Venezuela, Ministerio de agricultura y cria. Ser. Biol. 1/1, 9-31.

SUDEPE, (1988), Portaria $\mathrm{N}^{\circ} 17$, de 19 de agosto 1988, Art. $2^{\circ}$. Diário Oficial [da] República Federativa do Brasil de 25.08.88, Seção 1.
Valencia, J. S.; Re Regis, M. C.; Gonzalez, M. E.; De La Rosa, M. E. and Escalant, M. S. (1998), Reproductive characteristics of Anchoa hepsetus (Linnaeus, 1758, Piscres: Engraulidae) in Seybaplaya, Campeche, Mexico. Proc. Gulf Caribb. Fish. Inst., 50, 969-990.

Vendel, A. L.; Spach, H. L.; Lopes, S. C. G. and Santos, C. (2002) Structure and dynamics of fish assemblages in a tidal creek environment. Braz. Arch. Biol. Technol., 45, 365-373.
Received: April 04, 2006; Revised: March 07, 2007; Accepted: August 20, 2008. 